\title{
Does Hyperoxia Restrict Pyrenean Rock Lizards Iberolacerta bonnali to High Elevations?
}

\author{
Eric J. Gangloff ${ }^{1, *(\mathbb{D}}$, Sierra Spears ${ }^{1}$, Laura Kouyoumdjian ${ }^{2}$, Ciara Pettit ${ }^{1}$ and Fabien Aubret ${ }^{2}$ \\ 1 Department of Zoology, Ohio Wesleyan University, Delaware, OH 43015, USA; ssspears@owu.edu (S.S.); \\ clpettit@owu.edu (C.P.) \\ 2 Station d'Ecologie Théorique et Expérimentale du CNRS-UPR 2001, 09200 Moulis, France; \\ laura.kouyoumdjian@hotmail.fr (L.K.); fabien.aubret@sete.cnrs.fr (F.A.) \\ * Correspondence: ejgangloff@owu.edu
}

Citation: Gangloff, E.J.; Spears, S.; Kouyoumdjian, L.; Pettit, C.; Aubret, F. Does Hyperoxia Restrict Pyrenean Rock Lizards Iberolacerta bonnali to High Elevations?. Diversity 2021, 13, 200. https://doi.org/10.3390/ d13050200

\section{Academic Editors: Francisco}

Javier Zamora-Camacho, Mar Comas and Luc Legal

Received: 20 March 2021

Accepted: 5 May 2021

Published: 11 May 2021

Publisher's Note: MDPI stays neutra with regard to jurisdictional claims in published maps and institutional affiliations.

Copyright: (c) 2021 by the authors. Licensee MDPI, Basel, Switzerland. This article is an open access article distributed under the terms and conditions of the Creative Commons Attribution (CC BY) license (https:// creativecommons.org/licenses/by/ $4.0 /)$.

\begin{abstract}
Ectothermic animals living at high elevation often face interacting challenges, including temperature extremes, intense radiation, and hypoxia. While high-elevation specialists have developed strategies to withstand these constraints, the factors preventing downslope migration are not always well understood. As mean temperatures continue to rise and climate patterns become more extreme, such translocation may be a viable conservation strategy for some populations or species, yet the effects of novel conditions, such as relative hyperoxia, have not been well characterised. Our study examines the effect of downslope translocation on ectothermic thermal physiology and performance in Pyrenean rock lizards (Iberolacerta bonnali) from high elevation (2254 $\mathrm{m}$ above sea level). Specifically, we tested whether models of organismal performance developed from low-elevation species facing oxygen restriction (e.g., hierarchical mechanisms of thermal limitation hypothesis) can be applied to the opposite scenario, when high-elevation organisms face hyperoxia. Lizards were split into two treatment groups: one group was maintained at a high elevation (2877 m ASL) and the other group was transplanted to low elevation (432 m ASL). In support of hyperoxia representing a constraint, we found that lizards transplanted to the novel oxygen environment of low elevation exhibited decreased thermal preferences and that the thermal performance curve for sprint speed shifted, resulting in lower performance at high body temperatures. While the effects of hypoxia on thermal physiology are well-explored, few studies have examined the effects of hyperoxia in an ecological context. Our study suggests that high-elevation specialists may be hindered in such novel oxygen environments and thus constrained in their capacity for downslope migration.
\end{abstract}

Keywords: high elevation; hyperoxia; sprint performance; thermal performance curve; thermal preference

\section{Introduction}

Mountains cover approximately $30 \%$ of the world's land surface [1]. These biodiversity hotspots [2] harbour virtually all life forms (including diversity of bacteria [3,4], insects [5,6], arachnids [7], gastropods [8,9], fish [10,11], amphibians [12,13], mammals [14,15], birds [16], and squamate reptiles $[17,18])$. Mountain ecological landscapes are characterised by altitudinal zonation [19], where organisms tend to be adapted to a relatively narrow range of environmental conditions including colder temperature regimes (mean and extremes), strong UV irradiance, and lower atmospheric pressure, thus reduced oxygen availability as altitude increases. Although examples abound where geographically widespread species usually constrained to low elevation areas have successfully established along parts of the elevational gradient [20-23], plants and animals found in high altitudinal zones tend to become isolated since the conditions above and below a particular zone will be inhospitable and thus restrict their movements or dispersal. In extreme examples, such isolated ecological systems have been coined sky or continental islands $[16,24,25]$. 
Physiological adaptations to high-elevation life have attracted considerable scientific attention, including in humans, domesticated animals, and wild animal populations [26-28], notably in relation to colder temperature regimes, UV irradiance, and lower oxygen availability. However, it is less clear how such adaptations may prevent or hinder population movement, especially toward lower elevations. In other words, are populations found at high elevation effectively restricted to this elevation, and if so, why? Several non-exclusive hypotheses exist. Most obviously, environmental conditions below the current elevation may exceed the organisms' tolerance (i.e., beyond its fundamental niche), being too hot or too dry for instance [29-31]. Alternatively, lower-elevation niches may be exploited by a direct competitor, harbour a predator, or may lack a suitable food source [32-34].

One such example comes from an endemic trio of lizard species in the genus Iberolacerta, namely, I. aranica, I. aurelioi, and I. bonnali. These three species exhibit non-overlapping distributions between 1500 and $3100 \mathrm{~m}$ above sea level (ASL) in the Pyrénées mountains of southwestern Europe (France, Andorra, and Spain). They occur as a constellation of small populations, with high degrees of genetic isolation amongst populations of the three species [35,36] presumably due to very low dispersal rates amongst mountain peaks [37]. In the case of Iberolacerta, it was suggested that their restricted distribution resulted either (1) from their cold-adapted thermal physiology (i.e., low tolerance for high temperature, resulting in a reduction in their activity budgets by excess of heat [38-42]) or (2) from competitive exclusion from wall lizards (Podarcis spp. [43]). In support of the latter, some studies suggest that competition with Podarcis might affect the presence of high-elevation specialist Iberolacerta spp. through antagonistic interactions and competition for access to preferred thermal habitat ([44,45], but see [46]).

Recent studies [47,48] suggest that Podarcis may be suited to higher-elevation colonisation beyond its current range due to embryonic developmental resilience to lowered oxygen availability when transplanted to high elevation $(\approx 3000 \mathrm{~m}$ ASL), well above its maximum recorded elevation (i.e., $2200 \mathrm{~m}$ ASL $[35,49])$. Moreover, Podarcis is locally observed to expand its range upslope at a steady but rapid pace in the Pyrénées [49], suggesting that fast colonisation might occur in the coming decades. This will inevitably bring more Podarcis into contact with Iberolacerta and foster potential competition for territories, nesting sites, and food, as well as potentially exposing Iberolacerta to novel diseases and parasites. Current climate change will only facilitate this process [29,50,51]: high-altitude areas are warming faster than the global average [52-54], and Podarcis are a thermophilic species successful at establishing in new environments [43,55-58].

With this study, we tested an additional, non-exclusive hypothesis of the mechanism limiting Iberolacerta to high elevation: we propose that Iberolacerta species have adapted to high elevation hypoxia to a point where sea-level oxygen levels (hyperoxia, from Iberolacerta's perspective) may hinder organismal function. As an analogy, the metabolic cold adaptation hypothesis (MCA) predicts that ectotherms from colder environments (higher latitudes or elevations) will have elevated metabolic rates compared to those from warmer climates at a given temperature [59]. Increased metabolic rates are predicted to be adaptive by allowing accelerated physiological processes in environments that feature shorter periods of optimal conditions $[60,61]$. On the other hand, such adaptations become rapidly detrimental (i.e., metabolically very costly) if environment temperature increases (e.g., via climate change or dispersal). In the same manner, organisms adapted to maintaining organismal function in low-oxygen conditions may suffer under conditions of increased oxygen availability. For example, this may disrupt oxidative phosphorylation pathways that can either reduce the efficiency of aerobic metabolism or result in the production of potentially harmful byproducts [62-64].

To test this hypothesis, we studied the effect of translocation to low elevation on ectothermic thermal physiology and performance. Shifts in elevation most notably affect the total partial pressure exhibited by the atmosphere, which will reduce oxygen availability at high elevations and increase availability at low elevations. Utilising Pyrenean rock lizards 
(Iberolacerta bonnali), we measured traits known to have important consequences for both fitness and thermally-dependent physiological processes: sprint speed and preferred body temperature. If high-elevation specialists are able to process increased oxygen when available, we predicted both sprint speed and preferred body temperatures will increase, in the opposite direction from what has been observed in low-elevation organisms brought into hypoxia [65-67]. In contrast, under our novel proposal that hyperoxia limits high-elevation species from moving downslope, we predicted performance decrements and reduced preferred body temperatures after transplanting lizards to low elevation. Thus, we sought to understand how organisms are adapted to their specific oxygen environment and their potential behavioural and physiological responses to novel environments. Quantifying these responses is essential in addressing the question of whether abiotic factors, such as oxygen availability, represent absolute constraints on organismal performance or whether organisms are specifically adapted to the resources in their environment and any deviance from these levels - either increase or decrease — can restrict physiological processes and performance.

\section{Materials and Methods}

\subsection{Study Species}

The Pyrenean rock lizard (Iberolacerta bonnali Lantz, 1927; Figure 1) is a diurnal, heliothermic species endemic to the alpine and subalpine environments of the Pyrénées Mountains [35] and can be found at elevations between 1550 and $3062 \mathrm{~m}$ ASL [68]. Its annual period of activity is very short due to cold temperatures and the presence of snow most of the year $[35,68,69]$. This restricts their reproductive cycle to one clutch per year with an average of three eggs [70]. Being a highly endemic patrimonial species with a very restricted range, it is listed on the IUCN red list of threatened reptile species in Europe [71].

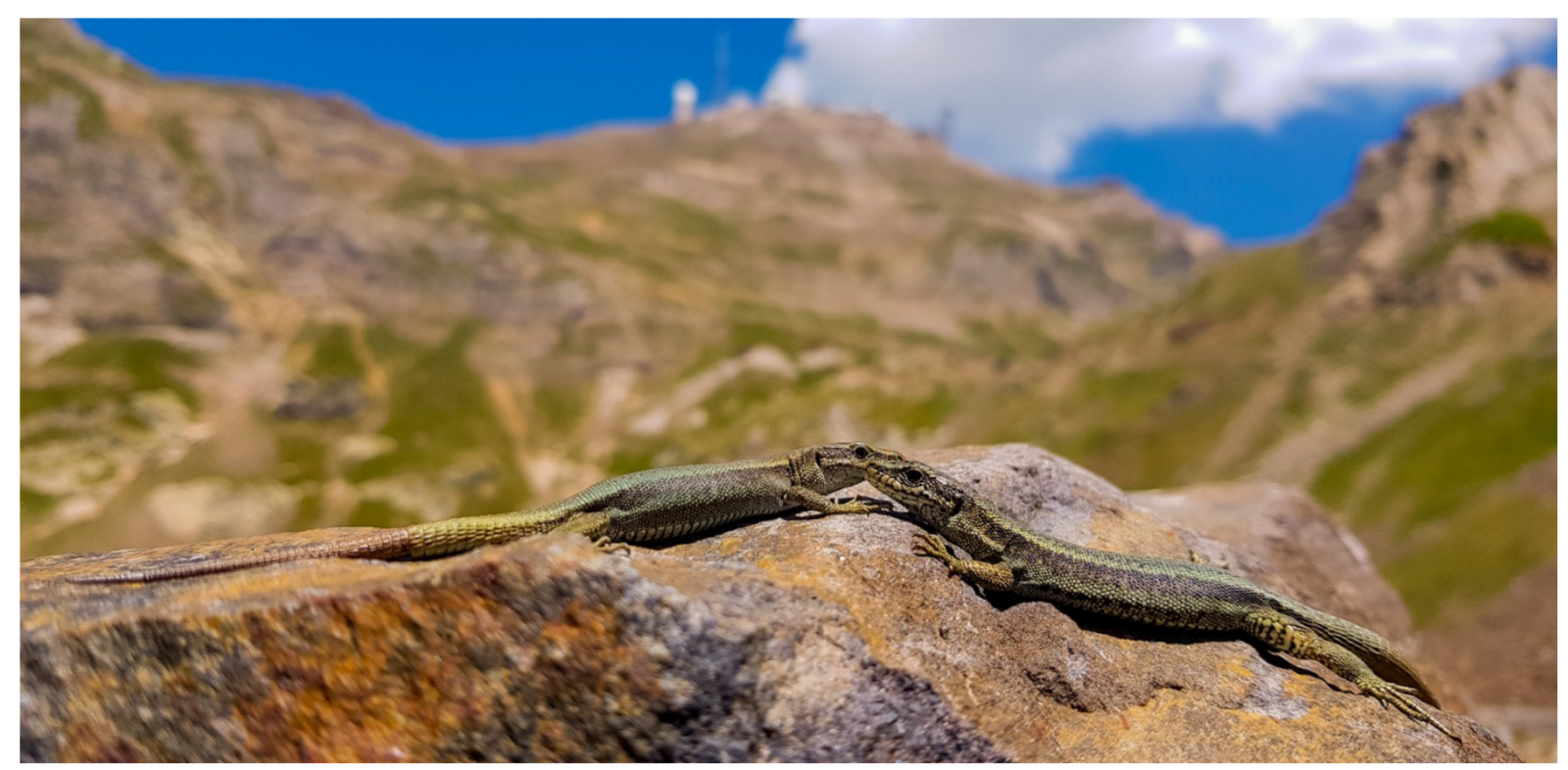

Figure 1. Two adult Iberolacerta bonnali basking in their natural environment. Photograph by Fabien Aubret.

\subsection{Experimental Design}

Since female reproductive status cannot always be ascertained (i.e., early vitellogenesis) and because carrying eggs may affect performance and thermoregulatory patterns in squamates [72-74], the study was carried out with male lizards only. We captured 40 male lizards around the Lac d'Oncet at $2254 \mathrm{~m}$ ASL (Department of Hautes-Pyrénées, France) between 2 and 7 July 2020 using the lasso method [75,76] during peak activity hours $(09 \mathrm{~h}$ 30-15 h 30). Immediately after capture (within $10 \mathrm{~s}$ ), body temperature was recorded with an infrared thermometer from a $30 \mathrm{~cm}$ distance (infrared thermometer Trotec BP21, 
Marchtrenk, Austria, distance:measurement spot ratio 12:1). On the day of capture, we measured the body mass with a precision scale to the nearest $0.01 \mathrm{~g}$ (range: 1.24-4.28; mean \pm s.d.: $2.64 \pm 0.83 \mathrm{~g}$ ) and the snout vent length (SVL) with a digital caliper to the nearest $0.1 \mathrm{~mm}$ (range: $38.9-56.0$; mean \pm s.d.: $48.19 \pm 5.22 \mathrm{~mm}$ ). Lizards were individually marked using a cautery pen [77]. For logistical reasons, the first 20 lizards captured were transported to the Station d'Ecologie Théorique et Expérimentale du CNRS à Moulis as the low-elevation treatment $\left(42^{\circ} 57^{\prime} 26.8^{\prime \prime} \mathrm{N}, 1^{\circ} 05^{\prime} 08.3^{\prime \prime} \mathrm{E} ; 436 \mathrm{~m}\right.$ ASL; $\left.\mathrm{PO}_{2} \approx 20.1 \mathrm{kPa}\right)$ and the following 20 others to the Observatoire du Pic de Midi de Bigorre $\left(42^{\circ} 56^{\prime} 11.09^{\prime \prime} \mathrm{N}\right.$, $0^{\circ} 8^{\prime} 32.9^{\prime \prime} \mathrm{E} ; 2877 \mathrm{~m}$ ASL; $\mathrm{PO}_{2} \approx 15.3 \mathrm{kPa}$ ). These differences in elevation result in about a $25 \%$ reduction in oxygen availability at the high elevation Pic du Midi lab compared with the low elevation lab [78]. Treatment groups did not differ in SVL $\left(t_{37.6}=0.035, p=0.97\right)$ or mass $\left(t_{37.9}=0.071, p=0.94\right)$ at the beginning of the experiment or in mass at the end of the experiment $\left(t_{36.9}=1.51, p=0.14\right)$.

Lizards were maintained under identical conditions in both labs so that the primary difference in environments was total atmospheric pressure and thus oxygen availability. While such experimental designs are not able to completely isolate the effects of reduction in oxygen availability from changes in total atmospheric pressure, they are essential complements to experiments that manipulate oxygen concentration in a controlled laboratory setting [79]. Lizards were housed in groups of $2-4$ in plastic enclosures $(38 \times 26 \times 23 \mathrm{~cm})$ containing a thin layer of substrate, a water container, and two plastic hides also used as thermoregulation platforms $(15 \times 5 \times 3.5 \mathrm{~cm})$. Every second day, lizards were fed with mealworms (Tenebrio sp. larvae) and white maggots (Calliphora vomitoria), and water was provided ad libitum. The cages were misted once a day. A UV lamp provided light for $11 \mathrm{~h}$ per day, and the enclosures were heated with incandescent heat lamps $(42 \mathrm{~W})$ for $6 \mathrm{~h}$ per day at $1 \mathrm{~h}$ intervals, providing a gradient of 20 to $36^{\circ} \mathrm{C}$. Animals stayed in captivity for 2 to 3 days before the start of the testing schedule (see below).

\subsection{Thermal Preferences}

We quantified lizard thermal preferences for both treatment groups using standard procedures in a thermal gradient. After two hours acclimating to ambient temperatures $\left(20^{\circ} \mathrm{C}\right)$ in their home cages, four lizards were placed in individual lanes of a thermal preference arena (each lane $90 \times 15 \mathrm{~cm}$ ). On one side of this arena, we suspended four ceramic lamps $(150 \mathrm{~W})$ to create a thermal gradient ranging from 20 to $60^{\circ} \mathrm{C}$. The animals were left undisturbed for a one-hour acclimation period. Using two thermal cameras (model C3, Flir Systems, Wilsonville, OR, USA) placed on tripods above the arena at a distance of approximately $1 \mathrm{~m}$, we captured images of the lizards on the gradient every $5 \mathrm{~min}$ for $3 \mathrm{~h}$. Temperature data were extracted from the thermographs with Flir Tools (v.6.4, Flir Systems). We extracted data from the image that had the best angle or clearest image of the lizard at a given timepoint. We used the area box tool to select pixels in the centre of each lizard dorsum. We used an emissivity value of 0.97 , appropriate for reptile skin $[80,81]$, and accounted for ambient temperature and the distance between camera and animal. Using the 36 values for each individual, we quantified the preferred temperature as the mean of the middle $50 \%$ (mean of interquartile range [82]). Data for one individual were excluded from analysis because this lizard wedged himself partially under the partition and did not move for the entire trial period.

\subsection{Performance Measurements}

Our goal was to create thermal performance curves for sprint speed for lizards in both treatment groups. We measured sprint performance at five temperatures, spanning the active range for this species $\left(15,22,29,32\right.$, and $\left.35^{\circ} \mathrm{C}[68,83]\right)$. We tested lizards at a maximum of two temperatures per day, with $6-16 \mathrm{~h}$ rest between trials. The experiment was conducted over three consecutive days. Before sprinting, we acclimated lizards for one hour in thermostatically controlled incubators (Aqualytic, Germany) at the test temperature. Room temperature was thermostatically controlled to $20^{\circ} \mathrm{C}$. We then sprinted lizards on a 
1-m level racetrack lined with artificial turf, recording trials with a video camera ( $25 \mathrm{fps}$, Sony Model HDR-XR160E, Sony Corporation, Tokyo, Japan) placed on a tripod directly above the track. Lizards were prompted to sprint from 2 to 6 lengths of the track (i.e., until the visually fastest running speed was obtained). Data were extracted from videos using Tracker software [84]. For each length performed by a lizard, we calculated the maximum speed as the longest distance a lizard traversed in a time step of $0.2 \mathrm{~s}$. We sprinted lizards from both treatments in the same order of test temperatures, from coolest to warmest, so that lizards in both groups would experience the exact same treatment order and to avoid any potentially detrimental effects of incubation at the highest temperatures, especially in the high-elevation treatment where animals may be more sensitive to high temperatures [65]. To account for the potential effects of acclimation on lizard performance, after the trials at the highest temperature, we again sprinted all lizards at $15{ }^{\circ} \mathrm{C}$ to test for changes in performance over time in captivity and to estimate repeatability of sprint performance over the duration of the experiment.

\subsection{Ethics Statement}

Field and lab protocols were conducted under permit from the Direction régionale de l'environnement, de l'aménagement et du logement (DREAL) Midi-Pyrénées (Arrêté Préfectoral No: 2017-s-02 du 30 mars 2017), under current ethical committee approval (APAFIS DAP\#16359), and in accordance with Directive 2010/63/EU on protection of animals used for Scientific Purposes. Animals were returned to the site of capture after experiments.

\subsection{Statistical Methods}

To test for differences between treatment groups in thermal preference, we first used Levene's test to assess differences in variance and a $t$-test, assuming unequal variances, to test for differences in the mean, implemented in the programming language $\mathrm{R}$ [85]. We utilised linear mixed models to assess the relative influence of elevation treatment (low/high), temperature (treated as a categorical effect), body size (SVL), and the interaction of treatment and temperature on sprint performance. We $\log _{10}$-transformed sprint speed before analysis to meet the assumption of normal distribution of residuals and included a random intercept for individual to account for repeated measures on the same animal. We used the package emmeans for post hoc comparisons of estimated marginal means, corrected for multiple comparisons with the Tukey method, in order to compare sprint speed between treatment groups at each temperature [86,87]. We implemented models with the lme4 package [88] in R. We confirmed normal distribution of residuals with a Shapiro-Wilk test and determined the relative importance of fixed effects using type III sums of squares, correcting denominator degrees of freedom for F-tests [89]. All data figures were created with the ggplot2 package [90]. Additionally, we assessed whether sprint speed changed over time in captivity by comparing sprint performance at $15^{\circ} \mathrm{C}$ between measures made after 3 days in captivity and after 6 days in captivity with a linear mixed model of $\log _{10}$-transformed sprint speed (as above), including the fixed effect of time of measurement and the random effect of individual. Further, we calculated repeatability of sprint performance at this temperature with the $r p t R$ package in $\mathrm{R}$ [91], using 1000 bootstraps and 1000 permutations to estimate $95 \%$ confidence intervals and a $p$-value, respectively.

\section{Results}

Field body temperatures at time of capture averaged $25.0^{\circ} \mathrm{C}\left(\mathrm{N}=31\right.$; range: $12.6-31.7^{\circ} \mathrm{C}$; Figure 2A). Transplanting lizards to low elevation affected both the mean $\left(t_{27.6}=-2.92\right.$, $p=0.0069)$ and variance $\left(F_{1,37}=14.7, p=0.0005\right)$ of thermal preference: lizards transplanted to low elevation exhibited lower thermal preferences and greater variance compared to lizards maintained at high elevation (low elevation mean \pm SD: $30.6 \pm 3.6^{\circ} \mathrm{C}$; high elevation mean \pm SD: $33.2 \pm 1.7^{\circ} \mathrm{C}$; Figure $2 \mathrm{~B}$ ). Elevation treatment, temperature, and the 
interaction of elevation treatment and temperature affected sprint performance (Table 1 , Figure 3). Lizards transplanted to low elevation were slower runners at the three highest temperatures $\left(29,32\right.$, and $\left.35^{\circ} \mathrm{C}\right)$, as demonstrated by post hoc comparison of estimated marginal means (Table 2, Figure 3). Snout-vent length also exhibited a marginal effect on sprint performance, with larger lizards sprinting faster $(\beta=0.0032 \pm 0.0016 \mathrm{SE}$; Table 1$)$. Sprint speed at $15{ }^{\circ} \mathrm{C}$ did not differ between the two measures made at the beginning and end of the experiment $\left(\beta=-0.023 \pm 0.015 \mathrm{SE} ; F_{1,39}=2.21, p=0.14\right)$, and individuals exhibited moderate repeatability of sprint performance at this temperature $(R=0.381$, 95\% CI: 0.084-0.619, $p=0.003$ ).

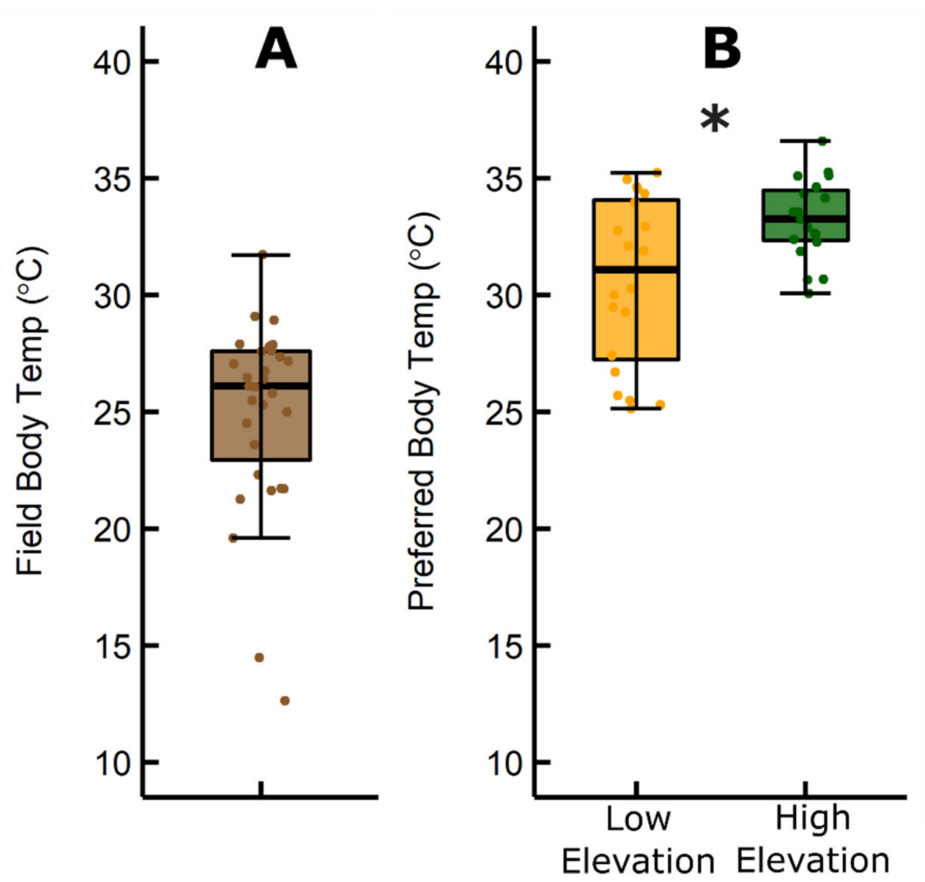

Figure 2. Boxplots and raw values of (A) field body temperatures and (B) thermal preferences of adult male Iberolacerta bonnali lizards. Thermal preferences (panel B) measured in lizards at low and high elevation. Tukey boxplots show median, interquartile range, and $1.5 \times$ interquartile range of raw data values. Asterisk indicates significant difference between treatment groups for thermal preference (see text for statistical details).

Table 1. Results of linear mixed model analysis of sprint performance ( $\log _{10}$-transformed $\left.\mathrm{m} / \mathrm{s}\right)$ in adult male Iberolacerta bonnali lizards at low and high elevation (see text for statistical details).

\begin{tabular}{cc}
\hline Source of Variation & Test Statistics \\
\hline Temperature & $114.8(4,152)$ \\
$F\left(d f_{n}, d f_{d}\right)$ & $<\mathbf{0 . 0 0 1}$ \\
$\operatorname{Pr}>\mathrm{F}$ & \\
Treatment & $5.13(1,37)$ \\
$F\left(d f_{n}, d f_{d}\right)$ & $\mathbf{0 . 0 3 0}$ \\
$\operatorname{Pr}>\mathrm{F}$ & \\
Temperature $\times$ Treatment & $2.84(4,152)$ \\
$F\left(d f_{n}, d f_{d}\right)$ & $\mathbf{0 . 0 2 6}$ \\
$\operatorname{Pr}>\mathrm{F}$ & $4.02(1,37)$ \\
Snout-vent length & 0.052 \\
$F\left(d f_{n}, d f_{d}\right)$ & \\
$\operatorname{Pr}>\mathrm{F}$ &
\end{tabular}

Significant effects shown in bold $(p<0.05)$. 


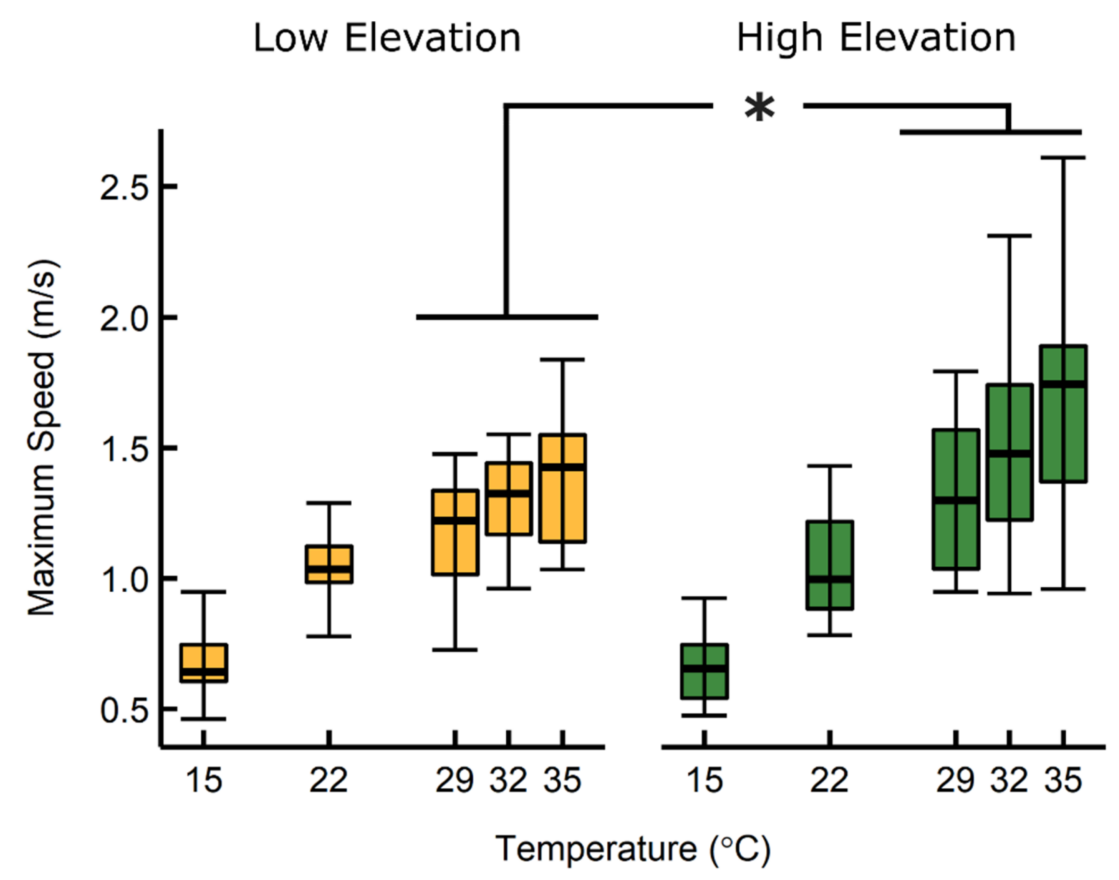

Figure 3. Boxplots of raw values for sprint performance in adult male Iberolacerta bonnali lizards at low and high elevation. Asterisk indicates significant difference between treatment groups at 29, 32, and $35^{\circ} \mathrm{C}$ (see text for statistical details).

Table 2. Estimated marginal means of $\log _{10}$-transformed transformed sprint speed $(\mathrm{m} / \mathrm{s})$ and differences between treatment groups at each temperature in adult male Iberolacerta bonnali lizards (see text for statistical details).

\begin{tabular}{ccccc}
\hline $\begin{array}{c}\text { Temperature } \\
\left({ }^{\circ} \mathbf{C}\right)\end{array}$ & $\begin{array}{c}\text { Low Elevation } \\
(\text { SE) }\end{array}$ & $\begin{array}{c}\text { High Elevation } \\
(\text { SE) }\end{array}$ & Difference (SE) & $\begin{array}{c}\text { Significance } \\
\text { Test }\end{array}$ \\
\hline \multirow{2}{*}{15} & -0.176 & -0.188 & 0.012 & $t_{171}=0.43$ \\
& $(0.02)$ & $(0.02)$ & $(0.29)$ & $p=0.668$ \\
22 & 0.022 & 0.013 & 0.009 & $t_{171}=0.33$ \\
& $(0.02)$ & $(0.02)$ & $(0.29)$ & $p=0.744$ \\
29 & 0.054 & 0.113 & -0.059 & $t_{171}=-2.068$ \\
& $(0.02)$ & $(0.02)$ & $(0.29)$ & $p=\mathbf{0 . 0 4 0}$ \\
32 & 0.103 & 0.171 & -0.068 & $t_{171}=0 .-2.39$ \\
& $(0.02)$ & $(0.02)$ & $(0.29)$ & $p=\mathbf{0 . 0 1 8}$ \\
35 & 0.134 & 0.212 & -0.079 & $t_{171}=-2.77$ \\
& $(0.02)$ & $(0.02)$ & $(0.29)$ & $p=\mathbf{0 . 0 0 6}$ \\
\hline
\end{tabular}

Significant differences at a given temperature shown in bold $(p<0.05)$.

\section{Discussion}

Previous work on vertebrate ectotherms demonstrates a near-universal limitation of performance and aerobic metabolic capacity under conditions of reduced oxygen availability, especially at high temperatures [65,92]. On the basis of this work, one would predict that a lizard species endemic to high-elevation habitats, and thus reduced oxygen availability, would demonstrate increased performance when exposed to a relatively hyperoxic environment. Our results are exactly contrary to this prediction, but in support of the hyperoxia-as-constraint hypothesis proposed in the introduction to this paper. When transplanted to low elevation, individuals of the high-elevation specialist $I$. bonnali suffered reduced sprint speed at high temperatures (Tables 1 and 2, Figure 3) and selected lower body temperatures in thermal preference trials (Figure 2B). Most of our understanding of oxygen limitation in ectothermic vertebrates comes from experiments reducing oxygen availability relative to the conditions in which organisms evolved or developed, and thus experiments such as the current study are essential for understanding more broadly how or- 
ganisms can deal with ecologically relevant levels of oxygen variation. Our results suggest strongly that adaptation to reduced oxygen environments restricts an organism's ability to take advantage of increased oxygen availability and, in fact, acute exposure to hyperoxia may be detrimental to performance and ultimately fitness. For example, limiting sprinting performance may have immediate consequences on lizards' ability to avoid predators or catch prey $[93,94]$.

While essential for aerobic life, oxygen is also toxic due to its ability to form molecules which attract electrons and can damage important biochemical structures [95-97]. Our results demonstrate that, even across ecologically relevant levels, acute increase in oxygen availability does not necessarily benefit whole-organism performance. This is in accord with previous work demonstrating that organisms that have evolved at near-sea-level conditions are unable to increase performance measures under hyperoxia [98]. For example, other lizard species exposed to hyperoxia do not alter selected body temperatures or behavioural response to high temperatures, although hyperoxia may increase physiological tolerance to high temperatures ([99-101], but see [102]). This suggests that multiple physiological pathways involved in aerobic respiration are fine-tuned to current oxygen environments, not simply limited by ambient oxygen levels. Therefore, deviations from baseline availability - either increase or decrease-may disrupt these pathways and lead to performance decrements. Future work is needed to examine the specific pathways and trade-offs involved. Our results suggest that, at their native elevation, lizards have evolved to meet metabolic demand when exposed to high temperatures despite low partial pressure of oxygen [103]. When more oxygen is available, these pathways can be dysregulated by hyperoxia in a manner that may disrupt the regulation of oxidative phosphorylation (ATP production) and increase the production of damaging reactive oxygen molecules (ROMs) in the mitochondria (reviewed in $[62,63]$ ). In our experiment, lizards transplanted to low elevation lowered their preferred body temperatures, which will result in reduced aerobic metabolic rates. This reduction of oxygen demand in the presence of increased oxygen availability could further exacerbate a potential increase in ROM production [104,105]. At the same time, this reduction in preferred body temperature coincides with a decrement in running performance at high temperatures in hyperoxia. Lizards may be avoiding warmer temperatures where performance is inhibited as a compensatory mechanism. Further work is needed to discern the specific signalling pathways that determine an individual's preferred temperature and how these may be disrupted by relative hyperoxia.

The mechanisms that restrict certain taxa to high-elevation habitats remain elusive. Most commonly, restriction to high-elevation habitats is attributed to either inability to inhabit warmer, low-elevation habitats (e.g., [25]) or due to the presence of competitors at lower elevations $[32,106,107]$, including specific examples in high-elevation specialist lizards of the genus Iberolacerta $[39,40,42,43,45,108]$. However, the congener Iberolacerta cyreni does not exhibit agonistic interactions with the low-elevation lizard Podarcis muralis either in experimental or field settings, providing little support for competitive exclusion restricting I. cyreni to high-elevation habitats [46,109]. Our results suggest that in addition to competitive interactions and cold-specialised thermal physiology, a third mechanismadaptation to low-oxygen environments and inability to deal with relative hyperoxiamay contribute to the elevation restriction observed in I. bonnali and potentially other Iberolacerta species. I. bonnali are extremely adept thermoregulators [83], suggesting that they could behaviourally buffer themselves in a warmer environment $[38,110]$. However, levels of oxygen ability will interact with available temperatures to shape thermal ecology (as described by the hierarchical mechanisms of thermal limitation hypothesis [65]). If thermoregulatory set-points are determined by the thermodynamic effects of temperature on metabolism, increased oxygen availability could disrupt the acquisition of optimal temperatures for different aspects of organismal function. For example, we found that I. bonnali transplanted to low elevations selected temperatures $2.6^{\circ} \mathrm{C}$ cooler than lizards kept close to the elevation of origin. This reduction in selected temperatures will likely result in a decrement in fitness-related physiological processes. Additionally, exposure 
to novel conditions might increase among-individual variation in traits when previously cryptic genetic variation is exposed [111,112]. In this case, increased among-individual variation in thermal preferences could indicate there is greater genetic variance-in trait means or plasticity - upon which natural selection could act in novel environments.

Our results suggest that the evolved capacities of I. bonnali to compensate for low oxygen availability in their high-elevation habitats may be maladaptive when lizards are translocated to low elevations and increased oxygen availability. The extent to which this limitation may be important in restricting the range of high-elevation specialists needs to be assessed in more taxa. The inability to adjust to relative hyperoxia may act in conjunction with other factors, such as increased interspecific competition or higher temperatures, to limit species distributions. Our data also suggest that I. bonnali may be resilient to shortterm increases in high temperatures. Their preferred body temperature in unconstrained laboratory conditions is well above temperatures lizards achieved in the field and they are capable of maintaining at least one measure of whole-organism performance, sprinting, at even the highest temperature we tested $\left(35^{\circ} \mathrm{C}\right)$. The important conservation question is then the capacity for lower-elevation species, such as lizards in the genus Podarcis, to move upslope and the potential ramifications of increased interspecific interactions, which remain unclear $[45,46,113]$.

Future studies should also test the response of high-elevation lizards when acclimated to low-elevation conditions for longer periods of time and how physiological plasticity might mitigate the negative consequences we observed, such as through shifts in blood oxygen capacity, reactive oxygen molecule production, or metabolic rates (e.g., [114]). Over longer exposures to relative hyperoxia, lizards may be able to respond via physiological plasticity to compensate for the new environment. For example, the congener I. cyreni dramatically reduced hematocrit, increased body condition, and increased preferred body temperatures after two weeks of exposure to a modest increase in oxygen availability [114]. However, such plasticity may not fully compensate, and performance can be reduced, as found in low-elevation lizards transplanted to high elevation (e.g., [66,115]). It is also essential to test the capacity of embryos to develop successfully in different oxygen environments, as this life-history stage may be more resilient to such limitations [48,116118]. Our results were directly opposite to predictions based on models developed from studies of organisms inhabiting generally normoxic environments introduced to conditions of oxygen limitation. This highlights the complexities of oxygen physiology and that the assumption of "more is better" does not apply to organisms adapted to life at high elevation. Studies of the unique physiological adaptations of high-elevation organisms remain an essential—and underexplored-area in characterising the vast biological diversity of our planet $[119,120]$.

Author Contributions: Conceptualisation, E.J.G. and F.A.; data curation, S.S., L.K. and F.A.; formal analysis, E.J.G.; funding acquisition, F.A.; investigation, S.S., L.K. and F.A.; methodology, E.J.G., S.S., C.P. and F.A.; project administration, F.A.; resources, F.A.; supervision, E.J.G. and F.A.; writingoriginal draft, E.J.G., L.K. and F.A.; writing-review and editing, E.J.G., S.S., L.K., C.P. and F.A. All authors have read and agreed to the published version of the manuscript.

Funding: The Summer Science Research Program at Ohio Wesleyan University, coordinated by L. Tuhela-Reuning, providing funding and support for Sierra Spears. We thank European INTERREG POCTEFA OPCC ADAPYR no. EFA346/19 and TULIP Laboratory of Excellence (ANR-10-LABX-41) for funding.

Data Availability Statement: All data used in analyses are freely available in the Mendeley Data Repository (http:/ /dx.doi.org/10.17632/pdwgvtc6sn.1, accessed on 1 April 2019).

Acknowledgments: We are grateful to the staff of the Observatoire Midi-Pyrénées at Pic du Midi for their hospitality. We also thank B. Bodensteiner for technical advice and support.

Conflicts of Interest: The authors declare no conflict of interest. 


\section{References}

1. Sayre, R.; Frye, C.; Karagulle, D.; Krauer, J.; Breyer, S.; Aniello, P.; Wright, D.J.; Payne, D.; Adler, C.; Warner, H.; et al. A New High-Resolution Map of World Mountains and an Online Tool for Visualizing and Comparing Characterizations of Global Mountain Distributions. Mt. Res. Dev. 2018, 38, 240-249. [CrossRef]

2. Hoorn, C.; Mosbrugger, V.; Mulch, A.; Antonelli, A. Biodiversity from mountain building. Nat. Geosci. 2013, 6, 154. [CrossRef]

3. Shen, C.; Shi, Y.; Fan, K.; He, J.-S.; Adams, J.M.; Ge, Y.; Chu, H. Soil pH dominates elevational diversity pattern for bacteria in high elevation alkaline soils on the Tibetan Plateau. FEMS Microbiol. Ecol. 2019, 95, 95. [CrossRef] [PubMed]

4. King, A.J.; Freeman, K.R.; McCormick, K.F.; Lynch, R.C.; Lozupone, C.; Knight, R.; Schmidt, S.K. Biogeography and habitat modelling of high-alpine bacteria. Nat. Commun. 2010, 1, 53. [CrossRef] [PubMed]

5. Birrell, J.H.; Shah, A.A.; Hotaling, S.; Giersch, J.J.; Williamson, C.E.; Jacobsen, D.; Woods, H.A. Insects in high-elevation streams: Life in extreme environments imperiled by climate change. Glob. Chang. Biol. 2020, 26, 6667-6684. [CrossRef]

6. Mani, M.S. Ecology and Biogeography of High Altitude Insects; Springer: Berlin/Heidelberg, Germany, 2013 ; Volume 4.

7. Thaler, K. The diversity of high altitude arachnids (Araneae, Opiliones, Pseudoscorpiones) in the Alps. In Alpine Biodiversity in Europe; Springer: Berlin/Heidelberg, Germany, 2003; pp. 281-296.

8. Baur, B.; Meier, T.; Baur, A.; Schmera, D. Terrestrial gastropod diversity in an alpine region: Disentangling effects of elevation, area, geometric constraints, habitat type and land-use intensity. Ecography 2014, 37, 390-401. [CrossRef]

9. Ports, M. Habitat affinities and distributions of land gastropods from the Ruby Mountains and East Humboldt Range of northeastern Nevada. Veliger 1996, 39, 335-341.

10. Atkinson, C.L.; Alexiades, A.V.; MacNeill, K.L.; Encalada, A.C.; Thomas, S.A.; Flecker, A.S. Nutrient recycling by insect and fish communities in high-elevation tropical streams. Hydrobiologia 2019, 838, 13-28. [CrossRef]

11. Tong, C.; Fei, T.; Zhang, C.; Zhao, K. Comprehensive transcriptomic analysis of Tibetan Schizothoracinae fish Gymnocypris przewalskii reveals how it adapts to a high altitude aquatic life. BMC Evol. Biol. 2017, 17, 74. [CrossRef]

12. Cordier, J.M.; Lescano, J.N.; Ríos, N.E.; Leynaud, G.C.; Nori, J. Climate change threatens micro-endemic amphibians of an important South American high-altitude center of endemism. Amphib. Reptil. 2020, 41, 233-243. [CrossRef]

13. Yang, X.; Wang, Y.; Zhang, Y.; Lee, W.-H.; Zhang, Y. Rich diversity and potency of skin antioxidant peptides revealed a novel molecular basis for high-altitude adaptation of amphibians. Sci. Rep. 2016, 6, 19866. [CrossRef]

14. Storz, J.F. Hemoglobin function and physiological adaptation to hypoxia in high-altitude mammals. J. Mammal. 2007, 88, 24-31. [CrossRef]

15. Badgley, C. Tectonics, topography, and mammalian diversity. Ecography 2010, 33, 220-231. [CrossRef]

16. Fjeldså, J.; Bowie, R.; Rahbek, C. The role of mountain ranges in the diversification of birds. Annu. Rev. Ecol. Evol. Syst. 2012, 43, 249-265. [CrossRef]

17. Cerdeña, J.; Farfán, J.; Quiroz, A.J. A high mountain lizard from Peru: The world's highest-altitude reptile. Herpetozoa $2021,34,61$. [CrossRef]

18. McCain, C.M. Global analysis of reptile elevational diversity. Glob. Ecol. Biogeogr. 2010, 19, 541-553. [CrossRef]

19. Cadena, C.D.; Kozak, K.H.; Gómez, J.P.; Parra, J.L.; McCain, C.M.; Bowie, R.C.K.; Carnaval, A.C.; Moritz, C.; Rahbek, C.; Roberts, T.E.; et al. Latitude, elevational climatic zonation and speciation in New World vertebrates. Proc. R. Soc. B 2012, $279,194-201$. [CrossRef]

20. Hodkinson, I.D. Terrestrial insects along elevation gradients: Species and community responses to altitude. Biol. Rev. 2005, 80, 489-513. [CrossRef]

21. Kindler, C.; Böhme, W.; Corti, C.; Gvoždík, V.; Jablonski, D.; Jandzik, D.; Metallinou, M.; Široký, P.; Fritz, U. Mitochondrial phylogeography, contact zones and taxonomy of grass snakes (Natrix natrix, N. megalocephala). Zool. Scr. 2013, 42, 458-472. [CrossRef]

22. Marshall, L.; Perdijk, F.; Dendoncker, N.; Kunin, W.; Roberts, S.; Biesmeijer, J.C. Bumblebees moving up: Shifts in elevation ranges in the Pyrenees over 115 years. Proc. R. Soc. B 2020, 287, 20202201. [CrossRef]

23. Dupoué, A.; Trochet, A.; Richard, M.; Sorlin, M.; Guillon, M.; Teuliere-Quillet, J.; Vallé, C.; Rault, C.; Berroneau, M.; Berroneau, M.; et al. Genetic and demographic trends from rear to leading edge are explained by climate and forest cover in a cold-adapted ectotherm. Divers. Distrib. 2020. [CrossRef]

24. Gifford, M.E.; Kozak, K.H. Islands in the sky or squeezed at the top? Ecological causes of elevational range limits in montane salamanders. Ecography 2012, 35, 193-203. [CrossRef]

25. Wiens, J.J.; Camacho, A.; Goldberg, A.; Jezkova, T.; Kaplan, M.E.; Lambert, S.M.; Miller, E.C.; Streicher, J.W.; Walls, R.L. Climate-change, extinction, and Sky Island biogeography in a montane lizard. Mol. Ecol. 2019, 28, 2610-2624. [CrossRef]

26. Monge, C.; Leon-Velarde, F. Physiological adaptation to high altitude: Oxygen transport in mammals and birds. Physiol. Rev. 1991, 71, 1135-1172. [CrossRef] [PubMed]

27. González-Morales, J.C.; Beamonte-Barrientos, R.; Bastiaans, E.; Guevara-Fiore, P.; Quintana, E.; Fajardo, V. A mountain or a plateau? Hematological traits vary nonlinearly with altitude in a highland lizard. Physiol. Biochem. Zool. 2017, 90, 638-645. [CrossRef] [PubMed]

28. Zhao, X.; Wu, N.; Zhu, Q.; Gaur, U.; Gu, T.; Li, D. High-altitude adaptation of Tibetan chicken from MT-COI and ATP-6 perspective. Mitochondrial DNA A 2016, 27, 3280-3288. [CrossRef] 
29. Sinervo, B.; Méndez-De-La-Cruz, F.; Miles, D.B.; Heulin, B.; Bastiaans, E.; Cruz, M.V.-S.; A Lararesendiz, R.; Martínez-Méndez, N.; Calderón-Espinosa, M.L.; Meza-Lázaro, R.N.; et al. Erosion of Lizard Diversity by Climate Change and Altered Thermal. Niches Sci. 2010, 328, 894-899. [CrossRef]

30. Rozen-Rechels, D.; Dupoué, A.; Lourdais, O.; Chamaillé-Jammes, S.; Meylan, S.; Clobert, J.; Le Galliard, J. When water interacts with temperature: Ecological and evolutionary implications of thermo-hydroregulation in terrestrial ectotherms. Ecol. Evol. 2019, 9, 10029-10043. [CrossRef] [PubMed]

31. Bachmann, J.C.; Van Buskirk, J. Adaptation to elevation but limited local adaptation in an amphibian. Evolution 2020. [CrossRef]

32. Brown, J.H.; Stevens, G.C.; Kaufman, D.M. The geographic range: Size, shape, boundaries, and internal structure. Annu. Rev. Ecol. Syst. 1996, 27, 597-623. [CrossRef]

33. Tingley, R.; Vallinoto, M.; Sequeira, F.; Kearney, M.R. Realized niche shift during a global biological invasion. Proc. Natl. Acad. Sci. USA 2014, 111, 10233-10238. [CrossRef] [PubMed]

34. Alexander, J.M.; Diez, J.M.; Levine, J.M. Novel competitors shape species' responses to climate change. Nature 2015, 525, 515-518. [CrossRef]

35. Pottier, G. Plan National d'Actions en Faveur des Lézards des Pyrénées; Nature Midi-Pyrénées: Bagnères de Bigorre, France, 2012; p. 125.

36. Berroneau, M. Atlas des Amphibiens et Reptiles d'Aquitaine; Cistude Nature: Le Haillan, Gironde, 2014; 257p.

37. Datcharry, R. Détectabilité en Montagne de Deux Lézards Rupicoles: Le Lézard des Murailles (Podarcis muralis) vs. le Lézard de Bonnal (Iberolacerta bonnali). Mémoire de Stage de Master 2 GBAT; Université Paul Sabatier: Toulouse, France, 2014.

38. Aguado, S.; Braña, F. Thermoregulation in a cold-adapted species (Cyren's Rock Lizard, Iberolacerta cyreni): Influence of thermal environment and associated costs. Can. J. Zool. 2014, 92, 955-964. [CrossRef]

39. Monasterio, C.; Shoo, L.P.; Salvador, A.; Siliceo, I.; Díaz, J.A. Thermal constraints on embryonic development as a proximate cause for elevational range limits in two Mediterranean lacertid lizards. Ecography 2011, 34, 1030-1039. [CrossRef]

40. Monasterio, C.; Verdú-Ricoy, J.; Salvador, A.; Díaz, J.A. Living at the edge: Lower success of eggs and hatchlings at lower elevation may shape range limits in an alpine lizard. Biol. J. Linn. Soc. 2016, 118, 829-841. [CrossRef]

41. Osojnik, N.; Žagar, A.; Carretero, M.A.; García-Muñoz, E.; Vrezec, A. Ecophysiological dissimilarities of two sympatric lizards. Herpetologica 2013, 69, 445-454. [CrossRef]

42. Žagar, A.; Carretero, M.A.; Marguč, D.; Simčič, T.; Vrezec, A. A metabolic syndrome in terrestrial ectotherms with different elevational and distribution patterns. Ecography 2018, 41, 1728-1739. [CrossRef]

43. Carranza, S.; Arnold, E.N.; Amat, F. DNA phylogeny of Lacerta (Iberolacerta) and other lacertine lizards (Reptilia: Lacertidae): Did competition cause long-term mountain restriction? Syst. Biodivers. 2004, 2, 57-77. [CrossRef]

44. Žagar, A.; Carretero, M.A.; Osojnik, N.; Sillero, N.; Vrezec, A. A place in the sun: Interspecific interference affects thermoregulation in coexisting lizards. Behav. Ecol. Sociobiol. 2015, 69, 1127-1137. [CrossRef]

45. Žagar, A.; Carretero, M.A.; Vrezec, A.; Drašler, K.; Kaliontzopoulou, A. Towards a functional understanding of species coexistence: Ecomorphological variation in relation to whole-organism performance in two sympatric lizards. Funct. Ecol. 2017, 31, 1780-1791. [CrossRef]

46. Monasterio, C.; Salvador, A.; Diaz, J.A. Competition with wall lizards does not explain the alpine confinement of Iberian rock lizards: An experimental approach. Zoology 2010, 113, 275-282. [CrossRef]

47. Cordero, G.A.; Karnatz, M.L.; Svendsen, J.C.; Gangloff, E.J. Effects of low-oxygen conditions on embryo growth in the painted turtle. Chrysemys. Picta. Integr. Zool. 2017, 12, 148-156. [CrossRef]

48. Kouyoumdjian, L.; Gangloff, E.J.; Souchet, J.; Cordero, G.A.; Dupoue, A.; Aubret, F. Transplanting gravid lizards to high elevation alters maternal and embryonic oxygen physiology, but not reproductive success or hatchling phenotype. J. Exp. Biol. 2019, 222, jeb206839. [CrossRef]

49. Mallard, F. Programme les Sentinelles du Climat-Tome IX: Connaitre et Comprendre pour Protéger les Espèces Animales et Végétales face au Changement Climatique; Cistude Nature: Le Haillan, Gironde, 2020; 822p.

50. Pecl, G.T.; Araújo, M.B.; Bell, J.D.; Blanchard, J.; Bonebrake, T.C.; Chen, I.-C.; Clark, T.D.; Colwell, R.K.; Danielsen, F.; Evengård, B.; et al. Biodiversity redistribution under climate change: Impacts on ecosystems and human well-being. Science 2017, 355, eaai9214. [CrossRef]

51. Parmesan, C. Ecological and evolutionary responses to recent climate change. Annu. Rev. Ecol. Evol. Syst. 2006, 37, 637-669. [CrossRef]

52. Chen, I.-C.; Hill, J.K.; Ohlemüller, R.; Roy, D.B.; Thomas, C.D. Rapid range shifts of species associated with high levels of climate warming. Science 2011, 333, 1024-1026. [CrossRef]

53. Bravo, D.N.; Araújo, M.B.; Lasanta, T.; Moreno, J.I.L. Climate change in Mediterranean mountains during the 21st century. AMBIO J. Hum. Environ. 2008, 37, 280-285. [CrossRef]

54. Walters, R.J.; Blanckenhorn, W.U.; Berger, D. Forecasting extinction risk of ectotherms under climate warming: An evolutionary perspective. Funct. Ecol. 2012, 26, 1324-1338. [CrossRef]

55. Beninde, J.; Feldmeier, S.; Veith, M.; Hochkirch, A. Admixture of hybrid swarms of native and introduced lizards in cities is determined by the cityscape structure and invasion history. Proc. R. Soc. B 2018, 285, 20180143. [CrossRef]

56. Brown, R.M.; Gist, D.H.; Taylor, D.H. Home range ecology of an introduced population of the European wall lizard Podarcis muralis (Lacertilia; Lacertidae) in Cincinnati, Ohio. Am. Midl. Nat. 1995, 133, 344-359. [CrossRef] 
57. While, G.M.; Williamson, J.; Prescott, G.; Horvathova, T.; Fresnillo, B.; Beeton, N.J.; Halliwell, B.; Michaelides, S.; Uller, T. Adaptive responses to cool climate promotes persistence of a non-native lizard. Proc. R. Soc. B 2015, 282, 20142638. [CrossRef] [PubMed]

58. Hedeen, S.E.; Hedeen, D.L. Railway-aided dispersal of an introduced Podarcis muralis population. Herp. Rev. $1999,30,57$.

59. Schaefer, J.; Walters, A. Metabolic cold adaptation and developmental plasticity in metabolic rates among species in the Fundulus notatus species complex. Funct. Ecol. 2010, 24, 1087-1094. [CrossRef]

60. Chown, S.L.; Gaston, K.J. Exploring links between physiology and ecology at macro-scales: The role of respiratory metabolism in insects. Biol. Rev. 1999, 74, 87-120. [CrossRef]

61. Lardies, M.A.; Bacigalupe, L.D.; Bozinovic, F. Testing the metabolic cold adaptation hypothesis: An intraspecific latitudinal comparison in a common woodlouse. Evol. Ecol. Res. 2004, 6, 567-578.

62. Muller, F.L.; Lustgarten, M.S.; Jang, Y.; Richardson, A.; Van Remmen, H. Trends in oxidative aging theories. Free Radic. Biol. Med. 2007, 43, 477-503. [CrossRef]

63. Costantini, D. Oxidative stress ecology and the d-ROMs test: Facts, misfacts and an appraisal of a decade's work. Behav. Ecol. Sociobiol. 2016, 70, 809-820. [CrossRef]

64. Balaban, R.S.; Nemoto, S.; Finkel, T. Mitochondria, oxidants, and aging. Cell 2005, 120, 483-495. [CrossRef] [PubMed]

65. Gangloff, E.J.; Telemeco, R.S. High temperature, oxygen, and performance: Insights from reptiles and amphibians. Integr. Comp. Biol. 2018, 58, 9-24. [CrossRef] [PubMed]

66. Gangloff, E.J.; Sorlin, M.; Cordero, G.A.; Souchet, J.; Aubret, F. Lizards at the peak: Physiological plasticity does not maintain performance in lizards transplanted to high altitude. Physiol. Biochem. Zool. 2019, 92, 189-200. [CrossRef]

67. Li, X.; Wu, P.; Ma, L.; Huebner, C.; Sun, B.; Li, S. Embryonic and post-embryonic responses to high-elevation hypoxia in a low-elevation lizard. Integr. Zool. 2020, 15, 338-348. [CrossRef]

68. Arribas, O.J. Habitat selection, thermoregulation and activity of the Pyrenean Rock Lizard Iberolacerta bonnali (Lantz, 1927). Herpetozoa 2009, 22, 146-166.

69. Arribas, O.J. Lagartija pirenaica-Iberolacerta bonnali. In Enciclopedia Virtual de los Vertebrados Españoles; Salvador, A., Marco, A., Eds.; Museo Nacional de Ciencias Naturales: Madrid, Spain, 2015.

70. Galán, P.; Arribas, O. Reproductive characteristics of the Pyrenean high-mountain lizards: Iberolacerta aranica (Arribas, 1993), I. aurelioi (Arribas, 1994) and I. bonnali (Lantz, 1927). Anim. Biol. 2005, 55, 163-190. [CrossRef]

71. Pottier, G.; Arthur, C.-P.; Weber, L.; Cheylan, M. Répartition des lézards du genre Iberolacerta Arribas, 1997 (Sauria: Lacertidae) en France. 3/3: Le Lézard de Bonnal, Iberolacerta bonnali (Lantz, 1927). Bull. Soc. Herp. Fr. 2013, 148, 425-450.

72. Sinervo, B.; Hedges, R.; Adolph, S.C. Decreased sprint speed as a cost of reproduction in the lizard Sceloporus occidentalis: Variation among populations. J. Exp. Biol. 1991, 155, 323-336. [CrossRef]

73. Díaz de la Vega-Pérez, A.H.; Barrios-Montiel, R.; Jiménez-Arcos, V.H.; Bautista, A.; Bastiaans, E. High-mountain altitudinal gradient influences thermal ecology of the Mesquite Lizard (Sceloporus grammicus). Can. J. Zool. 2019, 97, 659-668. [CrossRef]

74. Mathies, T.; Andrews, R. Influence of pregnancy on the thermal biology of the lizard, Sceloporus jarrovi: Why do pregnant females exhibit low body temperatures? Funct. Ecol. 1997, 11, 498-507. [CrossRef]

75. Blomberg, S.; Shine, R. Reptiles. In Ecological Census Techniques: A Handbook, 2nd ed.; Sutherland, W.J., Ed.; Cambridge University Press: Cambridge, UK, 2006; pp. 297-307.

76. Fitzgerald, L.A. Finding and Capturing Reptiles. In Reptile Biodiversity: Standard Methods for Inventory and Monitoring; McDiarmid, R.W., Foster, M.S., Guyer, C., Chernoff, N., Gibbons, J.W., Eds.; University of California Press: Oakland, CA, USA, 2012; pp. 77-88.

77. Vervust, B.; Van Damme, R. Marking lizards by heat branding. Herp. Rev. 2009, 40, 173.

78. Bouverot, P. Adaptation to Altitude-Hypoxia in Vertebrates; Spring: Berlin, Germany, 1985; p. 176.

79. Ewalts, M.; Dawkins, T.; Friend, A.T. Hypoxia research: To control or not to control? That is the question. J. Physiol. 2021, 599, 2141-2142. [CrossRef] [PubMed]

80. Luna, S.; Font, E. Use of an infrared thermographic camera to measure field body temperatures of small lacertid lizards. Herp. Rev. 2013, 44, 59-62.

81. Tattersall, G.J. Infrared thermography: A non-invasive window into thermal physiology. Comp. Biochem. Physiol. A 2016, 202, 78-98. [CrossRef] [PubMed]

82. Taylor, E.N.; Diele-Viegas, L.M.; Gangloff, E.J.; Hall, J.M.; Halpern, B.; Massey, M.D.; Rödder, D.; Rollinson, N.; Spears, S.; Sun, B.J.; et al. The thermal ecology and physiology of reptiles and amphibians: A user's guide. J. Exp. Zool. A 2020. [CrossRef] [PubMed]

83. Ortega, Z.; Mencia, A.; Perez-Mellado, V. The peak of thermoregulation effectiveness: Thermal biology of the Pyrenean rock lizard, Iberolacerta bonnali (Squamata, Lacertidae). J. Therm. Biol. 2016, 56, 77-83. [CrossRef]

84. Brown, D. Tracker: Video Analysis and Modeling Tool; Version 5.1.3; 2019; Available online: https://physlets.org/tracker/ (accessed on 1 April 2019).

85. R Core Team. R: A Language and Environment for Statistical Computing; R Foundation for Statistical Computing: Vienna, Austria, 2018.

86. Lenth, R.V. Least-squares means: The R package lsmeans. J. Stat. Soft. 2016, 69, 1-33. [CrossRef]

87. Lenth, R.V. Emmeans: Estimated Marginal Means, Aka Least-Squares Means; R Package Version 1.3.3; 2019; Available online: https: / /CRAN.R-project.org/package=emmeans (accessed on 1 April 2019). 
88. Bates, D.M.; Maechler, M.; Bolker, B.M.; Walker, S. Fitting linear mixed-effects models using lme4. J. Stat. Soft. 2015, 67, 1-48. [CrossRef]

89. Kenward, M.G.; Roger, J.H. Small sample inference for fixed effects from restricted maximum likelihood. Biometrics 1997, 53, 983-997. [CrossRef]

90. Wickham, H. Ggplot2: Elegant Graphics for Data Analysis; Springer: New York, NY, USA, 2009; p. 213.

91. Stoffel, M.A.; Nakagawa, S.; Schielzeth, H.; Goslee, S. RptR: Repeatability estimation and variance decomposition by generalized linear mixed-effects models. Method Ecol. Evol. 2017, 8, 1639-1644. [CrossRef]

92. Jackson, D.C. Temperature and hypoxia in ectothermic tetrapods. J. Therm. Biol. 2007, 32, 125-133. [CrossRef]

93. Irschick, D.J.; Garland, T., Jr. Integrating function and ecology in studies of adaptation: Investigations of locomotor capacity as a model system. Ann. Rev. Ecol. Syst. 2001, 32, 367-396. [CrossRef]

94. Miles, D.B. The race goes to the swift: Fitness consequences of variation in sprint performance in juvenile lizards. Evol. Ecol. Res. 2004, 6, 63-75.

95. Barja, G. Aging in vertebrates, and the effect of caloric restriction: A mitochondrial free radical production-DNA damage mechanism? Biol. Rev. Camb. Philos. Soc. 2004, 79, 235-251. [CrossRef] [PubMed]

96. Damiani, E.; Donati, A.; Girardis, M. Oxygen in the critically ill: Friend or foe? Curr. Opin. Anesthesio. 2018, 31, 129-135. [CrossRef]

97. Finkel, T.; Holbrook, N.J. Oxidants, oxidative stress and the biology of ageing. Nature 2000, 408, 239-247. [CrossRef] [PubMed]

98. Seibel, B.A.; Deutsch, C. Oxygen supply capacity in animals evolves to meet maximum demand at the current oxygen partial pressure regardless of size or temperature. J. Exp. Biol. 2020, 223, jeb210492. [CrossRef] [PubMed]

99. Guerrero, A.C.; VandenBrooks, J.M.; Riley, A.; Telemeco, R.S.; Angilletta, M.J., Jr. Oxygen supply did not affect how lizards responded to thermal stress. Integr. Zool. 2018, 13, 428-436. [CrossRef]

100. Hicks, J.W.; Wood, S.C. Temperature regulation in lizards: Effects of hypoxia. Am. J. Physiol. Reg. Integr. Comp. Physiol. 1985, 248, R595-R600. [CrossRef]

101. He, J.; Xiu, M.; Tang, X.; Wang, N.; Xin, Y.; Li, W.; Chen, Q. Thermoregulatory and metabolic responses to hypoxia in the oviparous lizard, Phrynocephalus przewalskii. Comp. Biochem. Physiol. A 2013, 165, 207-213. [CrossRef]

102. Shea, T.K.; DuBois, P.M.; Claunch, N.M.; Murphey, N.E.; Rucker, K.A.; Brewster, R.A.; Taylor, E.N. Oxygen concentration affects upper thermal tolerance in a terrestrial vertebrate. Comp. Biochem. Physiol. A 2016, 199, 87-94. [CrossRef]

103. McClelland, G.B.; Scott, G.R. Evolved mechanisms of aerobic performance and hypoxia resistance in high-altitude natives. Annu. Rev. Physiol. 2019, 81, 561-583. [CrossRef]

104. Voituron, Y.; Boel, M.; Roussel, D. Mitochondrial threshold for $\mathrm{H}_{2} \mathrm{O}_{2}$ release in skeletal muscle of mammals. Mitochondrion 2020, 54, 85-91. [CrossRef]

105. Koch, R.E.; Buchanan, K.L.; Casagrande, S.; Crino, O.; Dowling, D.K.; Hill, G.E.; Hood, W.R.; McKenzie, M.; Mariette, M.M.; Noble, D.W.A.; et al. Integrating mitochondrial aerobic metabolism into ecology and evolution. Trends Ecol. Evol. 2021. [CrossRef] [PubMed]

106. Lomolino, M.V.; Riddle, B.R.; Whittaker, A.L.; Brown, J.H. Biogeography; Sinauer Associates: Sunderland, MA, USA, $2010 ;$ p. 560.

107. Jankowski, J.E.; Robinson, S.K.; Levey, D.J. Squeezed at the top: Interspecific aggression may constrain elevational ranges in tropical birds. Ecology 2010, 91, 1877-1884. [CrossRef] [PubMed]

108. Ortega, Z.; Mencia, A.; Perez-Mellado, V. Are mountain habitats becoming more suitable for generalist than cold-adapted lizards thermoregulation? PeerJ 2016, 4, e2085. [CrossRef] [PubMed]

109. Monasterio, C.; Salvador, A.; Iraeta, P.; Díaz, J.A. The effects of thermal biology and refuge availability on the restricted distribution of an alpine lizard. J. Biogeogr. 2009, 36, 1673-1684. [CrossRef]

110. Ortega, Z.; Mencía, A.; Pérez-Mellado, V. Behavioral buffering of global warming in a cold-adapted lizard. Ecol. Evol. 2016, 6, 4582-4590. [CrossRef]

111. Levis, N.A.; Pfennig, D.W. Evaluating 'Plasticity-first' evolution in nature: Key criteria and empirical approaches. Trends Ecol. Evol. 2016, 31, 563-574. [CrossRef]

112. Lande, R. Adaptation to an extraordinary environment by evolution of phenotypic plasticity and genetic assimilation. J. Evol. Biol. 2009, 22, 1435-1446. [CrossRef]

113. Žagar, A.; Simčič, T.; Carretero, M.A.; Vrezec, A. The role of metabolism in understanding the altitudinal segregation pattern of two potentially interacting lizards. Comp. Biochem. Physiol. A 2015, 179, 1-6. [CrossRef]

114. Megía-Palma, R.; Jiménez-Robles, O.; Hernández-Agüero, J.A.; De la Riva, I. Plasticity of haemoglobin concentration and thermoregulation in a mountain lizard. J. Therm. Biol. 2020, 92, 102656. [CrossRef]

115. Jiang, Z.-W.; Ma, L.; Mi, C.-R.; Du, W.-G. Effects of hypoxia on the thermal physiology of a high-elevation lizard: Implications for upslope-shifting species. Biol. Lett. 2021, 17, 20200873. [CrossRef]

116. Cordero, G.A.; Andersson, B.A.; Souchet, J.; Micheli, G.; Noble, D.W.A.; Gangloff, E.J.; Uller, T.; Aubret, F. Physiological plasticity in lizard embryos exposed to high-altitude hypoxia. J. Exp. Zool. A 2017, 327, 423-432. [CrossRef] [PubMed]

117. Souchet, J.; Bossu, C.; Darnet, E.; Le Chevalier, H.; Poignet, M.; Trochet, A.; Bertrand, R.; Calvez, O.; Martinez-Silvestre, A.; Mossoll-Torres, M.; et al. High temperatures limit developmental resilience to high-elevation hypoxia in the snake Natrix maura (Squamata: Colubridae). Biol. J. Linn. Soc. 2020, 132, 116-133. [CrossRef] 
118. Souchet, J.; Gangloff, E.J.; Micheli, G.; Bossu, C.; Trochet, A.; Bertrand, R.; Clobert, J.; Calvez, O.; Martinez-Silvestre, A.; Darnet, E.; et al. High-elevation hypoxia impacts perinatal physiology and performance in a potential montane colonizer. Integr. Zool. 2020, 15, 544-557. [CrossRef] [PubMed]

119. Storz, J.F. High-altitude adaptation: Mechanistic insights from integrated genomics and physiology. Mol. Biol. Evol. 2021. [CrossRef]

120. Li, J.T.; Gao, Y.D.; Xie, L.; Deng, C.; Shi, P.; Guan, M.L.; Huang, S.; Ren, J.L.; Wu, D.D.; Ding, L.; et al. Comparative genomic investigation of high-elevation adaptation in ectothermic snakes. Proc. Natl. Acad. Sci. USA 2018, 115, 8406-8411. [CrossRef] 